УДК $631.1 .016+334.732$

DOI: $10.15673 /$ fie.v10i3.1067

\author{
Нікішина О.В. \\ доктор економічних наук, старший науковий співробітник \\ відділ ринкових механізмів та структур \\ Інститут проблем ринку та економіко-екологічних досліджень НАН України \\ Французький бульвар, 29, м. Одеса, Україна, 65044 \\ E-mail: ksenkych@gmail.com
}

\title{
ІНТЕГРАЦІЙНИЙ ПІДХІД ДО ФОРМУВАННЯ ПРОГРАМИ РОЗВИТКУ ЗЕРНОВИХ БАГАТОФУНКЦІОНАЛЬНИХ КООПЕРАТИВІВ В УКРАÏHI
}

У статті досліджено проблемні аспекти дії формальних інститутів у сфері зернової кооперації, визначено причини їх інституційної неспроможності в українських реаліях. Доведено необхідність зміни методологічного підходу до фрормування програмних документів для реалізації потужного потенціалу кооперації індивідуальних зернових господарств. Обґрунтовано сутність інтеграційного підходу, який акцентує увагу на становленні й розвитку ефективних форм взаємодій між кооперативами, інституціями, ринковими суб'єктами на засадах узгодження їх економічних інтересів для досягнення цільового орієнтиру. Держава шляхом використання селективних заходів ініціює створення і підтримку цільового ланцюга доданої вартості, здатного об'єднати учасників процесу відтворення стратегічних видів зернових культур. Обґрунтовано головні етапи, умови взаємодій учасників та очікувані ефректи програми розвитку зернових багатофункціональних кооперативів в Україні. Підкреслено можливість їх відтворювального розвитку без державної підтримки за умови формування злагодженої системи інтеграційних взаємодій між кооперативами та учасниками процесу відтворення.

Ключові слова: зернова кооперація, індивідуальні господарства, багатофункціональні кооперативи, інтеграційні взаємодії, селективні заходи.

This work is licensed under a Creative Commons Attribution 4.0 International License http://creativecommons.org/licenses/by/4.0/

Постановка проблеми та її зв'язок з важливими науковими та практичними завданнями. Однією із проблем інституціоналізації процесу зернової кооперації в Україні $\epsilon$ невисока інституційна спроможність програмних документів державного й регіонального рівнів, обумовлена як недостатнім рівнем їх ресурсного, організаційного й контролюючого забезпечення, так і односпрямованою орієнтацією програм, що діяли, на розвиток одного локального сектору ринку без врахування його інтеграційних зв'язків і взаємодій з іншими секторами або ринками системи. В умовах обмеженості бюджетних ресурсів актуалізується завдання їх цілеспрямованого використання на вирішення головних проблем розвитку не одного, а декількох секторів товарного ринку за етапами виробничо-логістичного ланцюга, шляхом розробки та впровадження системних селективних заходів державного впливу.

Вказані завдання узгоджуються із Стратегією розвитку аграрного сектору економіки на період до 2020 року [1]. Також обраний напрям дослідження $\epsilon$ розвитком нової парадигми багатофункціонального розвитку сільських територій, яка отримала поширення в країнах Свропи і базується на полісекторному підході до розвитку сільської економіки.

Аналіз останніх публікацій по проблемі. Теоретико-методичні засади формування інституцій- ного середовища аграрної кооперації, у т.ч. зернового напряму, висвітлені в працях вітчизняних й іноземних економістів Р. Я. Корінця, М. Й. Маліка [2], О. В. Манжури [3], Л. В. Молдаван, О. В. Шубравської [4], І.М. Паски [5], Д. Норта [6], Е. Фуруботна, Р.Ріхтера [7] та інших учених. Водночас додаткових досліджень потребує питання розробки формальних інститутів, цілеспрямовано зорієнтованих на системне вирішення проблем не одного локального сектору, а декількох пов'язаних секторів ринку зерна та продуктів його переробки, підвищення ступеню стабілізуючого впливу нормативно-правових актів на розвиток процесів зернової кооперації в Україні.

Формулювання цілей дослідження. Мета статті - обгрунтування та розробка на основі інтеграційного підходу Державної цільової програми розвитку зернових багатофункціональних кооперативів в Україні (далі - Програма) - окреслила низку завдань:

1) аналіз проблемних аспектів дії формальних інститутів у сфері аграрної кооперації, причин їх виникнення в українських реаліях;

2) обгрунтування сутності інтеграційного підходу до формування Програми розвитку зернових багатофункціональних кооперативів (далі - ЗБК);

3) визначення заходів селективного впливу держави на формування інтеграційних зв' язків між 
учасниками ринкового процесу відтворення в розрізі етапів Програми, очікуваних ефектів від іiі практичного впровадження.

Виклад основних результатів та їх обгрунтування. Зерновий ринок України має потужний потенціал кооперації суб'єктів індивідуального сектору (таблиця 1). За період 1990-2017 рр. частка індивідуального сектору у валовому зборі зернових культур зросла з 2,84 \% до 36,66 \% за одночасного скорочення частки корпоративного сектору з 97,16\% до $63,34 \%$ відповідно. Одним із головних інструментів залучен- ня індивідуальних зернових господарств, у т.ч. господарств населення, до засобів ринкової інфраструктури, подолання залежності від цінової політики трейдерів і приватних елеваторів, забезпечення паритетності розподілу доходів між корпоративним і індивідуальним секторами ринку є створення мережі регіональних зернових кооперативів. Їх невелика кількість (35 одиниць - $6 \%$ від загальної кількості аграрних обслуговуючих кооперативів [8]) $є$ наочним свідченням низької ефективності діючих регуляторних механізмів у сфері кооперації, зокрема інституційних

Таблиця 1

Динаміка та структура (в розрізі категорій господарств) валового збору зернових культур в Україні, млн. т*

\begin{tabular}{|c|c|c|c|c|c|c|c|c|}
\hline \multirow{2}{*}{ Сектори } & \multicolumn{8}{|c|}{ Роки } \\
\hline & 1990 & 2000 & 2010 & 2013 & 2014 & 2015 & 2016 & 2017 \\
\hline 1. Корпоративний сектор & 49,56 & 18,7 & 25,08 & 42,14 & 42,21 & 38,86 & 43,14 & 39,22 \\
\hline $\begin{array}{l}\text { 2. Індивідуальний сектор, } \\
\text { усього, в т.ч.: }\end{array}$ & 1,45 & 5,76 & 14,19 & 20,91 & 21,65 & 21,27 & 22,95 & 22,70 \\
\hline $\begin{array}{l}\text { 2.1. Фермерські господар- } \\
\text { ства }\end{array}$ & 0 & 1,26 & 4,7 & 7,52 & 7,69 & 7,65 & 8,88 & 8,69 \\
\hline $\begin{array}{l}\text { 2.2. Господарства насе- } \\
\text { лення }\end{array}$ & 1,45 & 4,5 & 9,49 & 13,39 & 13,96 & 13,62 & 14,07 & 14,01 \\
\hline Усього: & 51,01 & 24,46 & 39,27 & 63,05 & 63,86 & 60,13 & 66,09 & 61,92 \\
\hline \multicolumn{9}{|c|}{ Структура виробництва (суб'сктний розріз), \% } \\
\hline 1. Корпоративний сектор & 97,16 & 76,45 & 63,87 & 66,84 & 66,10 & 64,62 & 65,28 & 63,34 \\
\hline $\begin{array}{l}\text { 2. Індивідуальний сектор, } \\
\text { усього, в т.ч.: }\end{array}$ & 2,84 & 23,55 & 36,13 & 33,16 & 33,90 & 35,37 & 34,72 & 36,66 \\
\hline $\begin{array}{l}\text { 2.1. Фермерські господар- } \\
\text { ства }\end{array}$ & 0,00 & 5,15 & 11,97 & 11,93 & 12,04 & 12,72 & 13,44 & 14,03 \\
\hline $\begin{array}{l}\text { 2.2. Господарства насе- } \\
\text { лення }\end{array}$ & 2,84 & 18,40 & 24,17 & 21,24 & 21,86 & 22,65 & 21,28 & 22,63 \\
\hline Усього: & 100,0 & 100,0 & 100,0 & 100,0 & 100,0 & 100,0 & 100,0 & 100,0 \\
\hline
\end{tabular}

"Розраховано автором за даними Державної служби статистики України [9]

Проведений аналіз положень Законів України «Про кооперацію» [10] та «Про сільськогосподарську кооперацію» [11] дозволяє визначити їх основний недолік, який полягає у відсутності чітко визначених механізмів і форм взаємодї держави й кооперативів. У ст. 15 Закону України «Про сільськогосподарську кооперацію» зазначається, що «державна підтримка аграрних обслуговуючих кооперативів здійснюється відповідно до державних та регіональних програм за рахунок державного і місцевих бюджетів у порядку, встановленому законом» [11]. На наш погляд, положення цієї статті є надзвичайно загальними та декларативними. Адже вони не визначають ні форми, ні змісту взаємодії держави й аграрних кооперативів. По суті, Закон передбачає лише саму можливість надання державою підтримки розвитку аграрної кооперації, але не містить організаційно-правового механізму взаємодії між відповідними органами державної влади та органами місцевого самоврядування, 3 одного боку, та кооперативами, з іншого.

Окремі складові механізмів державної підтримки аграрних кооперативів в Україні викладені в програмних документах. Так, у 2000 р. було затверджено Програму становлення і розвитку сільськогосподарських обслуговуючих кооперативів як неприбуткових організацій [12]. У p. IV Програми окреслено механізм і пріоритети фінансового забезпечення кооперативів. Програма передбачала створення Фонду підтримки розвитку сільськогосподарських обслуговуючих кооперативів, який надавав би допомогу новоствореним кооперативам в отриманні кредитів комерційних банків, гарантії їх повернення, частковій сплаті страхових платежів та іншу фінансову допомогу [12]. На практиці дану формальну інституцію створено не було.

3 метою удосконалення правових, соціальноекономічних та організаційних умов для створення кооперативів, формування їх інфраструктури Кабінетом Міністрів України 3 червня 2009 р. було прийнято Державну цільову економічну програму підтримки розвитку сільськогосподарських обслуговуючих кооперативів на період до 2015 р. [13]. Цією програмою передбачено удосконалення механізму державної підтримки розвитку кооперативів та створення до 
2,5 тис. таких кооперативів [13]. Практика показала, що Державна цільова програма діяла лише протягом 2009-2011 рр., коли для підтримки кооперативів виділялися бюджетні кошти. У 2010 р. обсяг фінансування видатків на підтримку кооперативів склав 10,4 млн. грн., у 2011 р. він зменшився удвічі і склав 5 млн. грн. Станом на 01.01.2016 р. в Україні зареєстровано 1,03 тис. сільськогосподарських обслуговуючих кооперативів [8], що складає 41,2 \% від планового показника. Програма втратила чинність 07.07.2011 р., іiі планові показники не були досягнуті, що $є$ свідченням низької регуляторної ефективності документу.

Однією з головних причин цього, на думку Р. Корінця й М. Маліка, окрім недостатнього фінансового забезпечення, є відсутність «механізму примусу» для реалізації правових норм та державних програм, зокрема, відсутність інститутів (як формальних, так і неформальних) щодо відповідальності посадових осіб за невиконання програм. Галузеві й державні програми є зразком «інституиійної неспроможності через відсутність ресурсного забезпечення» [2, с. 65]. Сьогодні в Україні немає державної цільової програми підтримки розвитку сільськогосподарських обслуговуючих кооперативів, водночас окремі компоненти завдання розвитку аграрної кооперації, у т.ч. зернової, знайшли відображення у нових нормативноправових актах, прийнятих у 2013-2015 рр., зокрема у Стратегії розвитку аграрного сектору економіки на період до 2020 р. № 806-р від 17.11.2013 р. [1]. Ретро- спективний аналіз програмних документів свідчить про їх неефективність, обумовлюючи об'єктивну необхідність зміни методологічного підходу до їх формування.

Проведені автором дослідження [14, 15] дозволили обгрунтувати гіпотетичне твердження про взаємопов'язаність головних економічних проблем розвитку суб'єктів різних секторів зернового ринку (рис. 1). Так, низький внутрішній попит на якісний насіннєвий матеріал обумовлений, зокрема, невисокими фінансовими можливостями первинних зерновиробників індивідуального сектору ринку, які, в освою чергу, обмежені існуючими дисбалансами в перерозподілі доходів на користь трейдерів і великих агрохолдингів. 3 іншого боку, домінуюча експортна орієнтованість даних суб'єктів корпоративного сектору змінила структуру зернового виробництва, що призвело до дефіциту стратегічних видів зернових культур на внутрішньому ринку. Як наслідок, незважаючи на потужний природно-ресурсний потенціал, вітчизняні зернопереробні підприємства не можуть сформувати належну за обсягами й якісними параметрами сировинну базу, достатню для задоволення потреб внутрішнього попиту й поетапного розвитку експортного напрямку.

Таким чином, виникає необхідність у цілеспрямованому управлінні товарними потоками різних секторів зернового ринку для системного вирішення головних проблем розвитку їх суб'єктів (див. рис. 1).

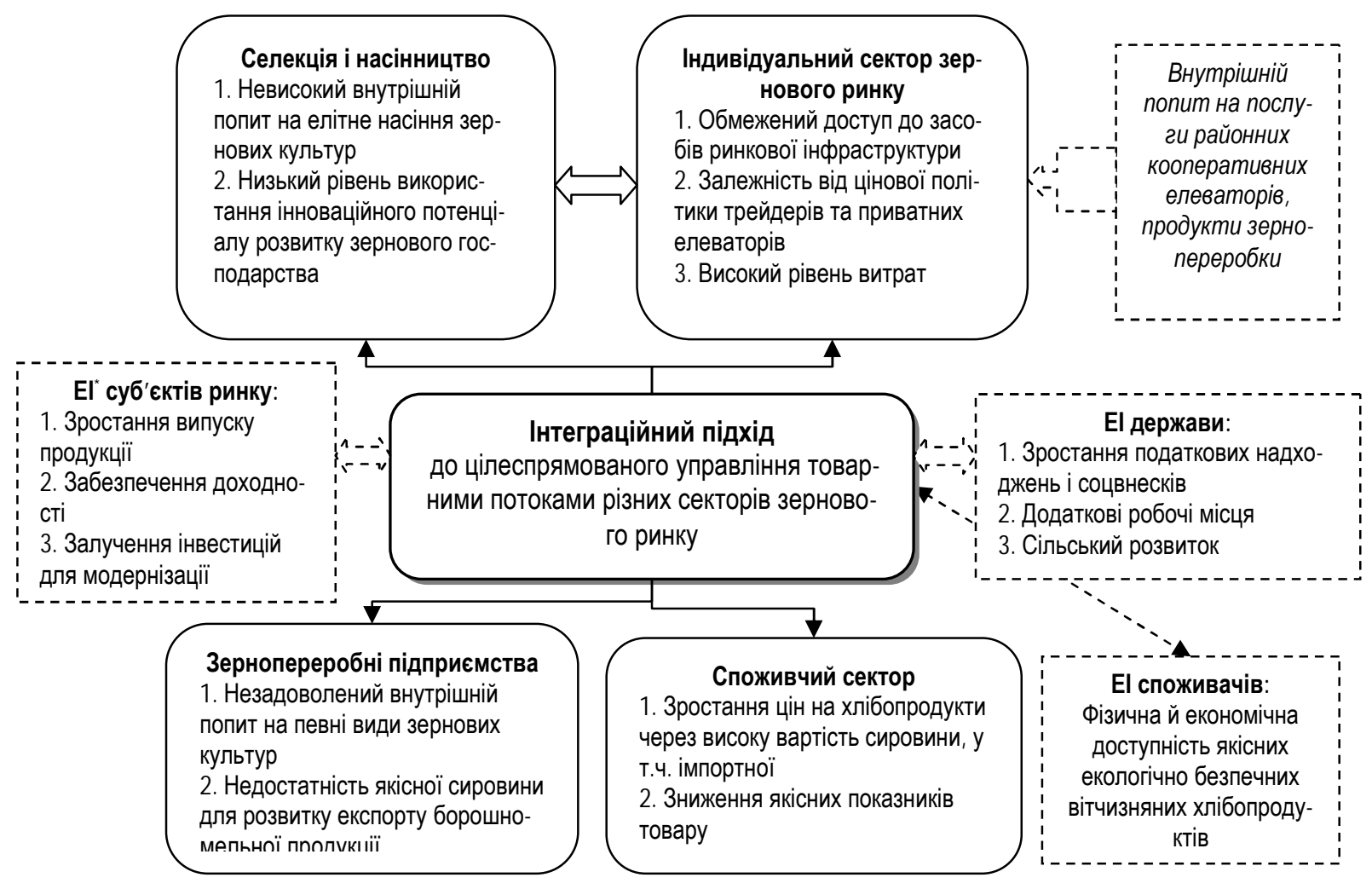

"ЕІ - економічні інтереси.

Рис. 1. Взаємопов’язаність головних проблем розвитку секторів зернового ринку України * *авторська розробка 
Інтеграчійний підхід, який пропонується використати в ході розбудови керованою державою системи управління товаропотоками, передбачає, 3 одного боку, налагодження i розвиток інтеграційних зв'язків між секторами і ринками за етапами виробничо-логістичного ланцюга, 3 іншого, узгодження економічних інтересів учасників ринкового процесу відтворення в ході досягнення багаторівневого цільового орієнтиру. Відтак, інтеграційний підхід орієнтований на кероване формування, поєднання й використання товарних і організаційних ресурсів суб'єктів та держави на засадах узгодження (поєднання) їх економічних інтересів для відтворювального розвитку секторів зернового ринку.

Практичне впровадження інтеграційного підходу до цілеспрямованого управління товарними потоками різних ринкових секторів обумовлює необхідність його інституціоналізації, тобто затвердження у законодавчому порядку необхідності та умов взаємодії товарно-фінансових потоків між суб'єктами насіннєвого ринку, індивідуальними зерновими господарствами та зернопереробними підприємствами. Формування розгалуженої системи інтеграційних зв'язків між учасниками процесу відтворення повинно відбуватися за активної участі державних і профільних інституцій та 3 використанням селективних регуляторних заходів, особливо на початковому етапі. Однією із форм інституціоналізації може бути Державна цільова програми підтримки розвитку ЗБК в Україні. Розглянемо її зміст більш детально.

Подолання структурних дисбалансів у виробництві та внутрішній реалізації зерна (за збутовими каналами), домінуючої сировинної спрямованості українського агроекспорту, обумовлює необхідність зміщення акцентів у державній політиці з підтримки трейдерів до підтримки виробників продуктів переробки 3 високою доданою вартістю. У багатьох районах країни існує незадоволений внутрішній попит як на послуги лінійних елеваторів, так і на зернові й хлібні продукти місцевого виробництва. Ця обставина визначає доцільність створення та розвитку не просто заготівельно-збутових, а багатофункціональних кооперативів, які органічно поєднують зберігання і переробку зерна, мають в своєму складі як кооперативний елеватор, так і зернопереробні потужності. На думку Л. В. Молдаван і О. В. Шубравської, наявність переробних потужностей підвищує економічну стійкість сільськогосподарських підприємств, а також допомагає вирішити проблему забезпечення зайнятості сільського населення, тобто сприяє сталому розвиткові господарського комплексу [4, с. 84]. Відтак, формування кооперативного сектору в переробній промисловості покликано забезпечити економічну стійкість та ефективність ЗБК, а також отримання соціального ефекту.

Головною метою Державної цільової програми підтримки розвитку зернових багатофункціональних кооперативів в Україні, що пропонується, є зменшення витрат індивідуальних господарств у про- цесі виробництва та реалізації зерна й продуктів його переробки, а також задоволення внутрішнього попиту на стратегічні види зернових культур, зокрема, продовольчої пшениці 2 класу, пшениці твердих сортів, жита, зернобобових культур.

Головна ідея, що закладена в основу Програми, полягає в наданні державою селективної підтримки ЗБК, члени яких виробляють і зберігають (частково переробляють) стратегічні види зернових культур iз певними параметрами якості для задоволення потреб вітчизняних переробних підприємств. Використовуючи селективні регуляторні заходи, держава здійснює цілеспрямоване управління процесами формування та перерозподілу товарних потоків у багаторівневій ринковій системі для досягнення головної мети Програми.

На практиці впровадження інтеграційного підходу (див. рис. 1) передбачає виникнення та розвиток множини інтеграційних зв'язків та взаємодій новоствореного ЗБК з іншими учасниками процесу відтворення. При цьому завдання держави набуває дворівневого значення: (1) стимулювати розвиток ЗБК на початковому етапі їх становлення в Україні; (2) сприяти формуванню ефективних форм взаємодії кооперативів з іншими ринковими суб'єктами та інституціями (рис. 2). Саме успішне виконання другого завдання дозволить забезпечити ефективне функціонування мережі регіональних ЗБК в Україні та створити передумови для їх подальшого відтворювального розвитку без державної підтримки.

Формування ефективних форм взаємодії передбачає об'єднання індивідуальних зернових господарств із іншими суб'єктами ринку, державними й профільними інституціями в єдиний злагоджений процес відтворення стратегічних видів зернових культур на засадах узгодження їх економічних інтересів. Інтегратором у даній системі виступає ЗБК певної спеціалізації як форма суб'єктної інтеграції індивідуальних господарств. Взаємозв'язки кооперативу 3 іншими учасниками ринкового процесу відтворення формуються на основі контрактної інтеграції, а також інтеграції організаційних ресурсів різних інституцій.

Контрактна інтеграчія є однією із форм вертикальної інтеграції. У країнах СС кооперативи формують горизонтальні зв'язки між фермерськими господарствами і більш складні елементи - вертикальну інтеграцію (переробка сільськогосподарської сировини, оптова торгівля тощо). Створення кінцевого продукту за вертикальної кооперації базується на поєднанні матеріально-технічних ресурсів, маркетингових, агросервісних послуг з боку обслуговуючих кооперативів та земельних і трудових ресурсів з боку виробничих кооперативів [3, с. 23]. Також до вказаних зв'язків контрактної інтеграції можна додати інвестиційні ресурси держави, організаційні та інформаційні ресурси державних, профільних і міжнародних інституцій, що діють у сфері аграрної, у т.ч. зернової кооперації. 


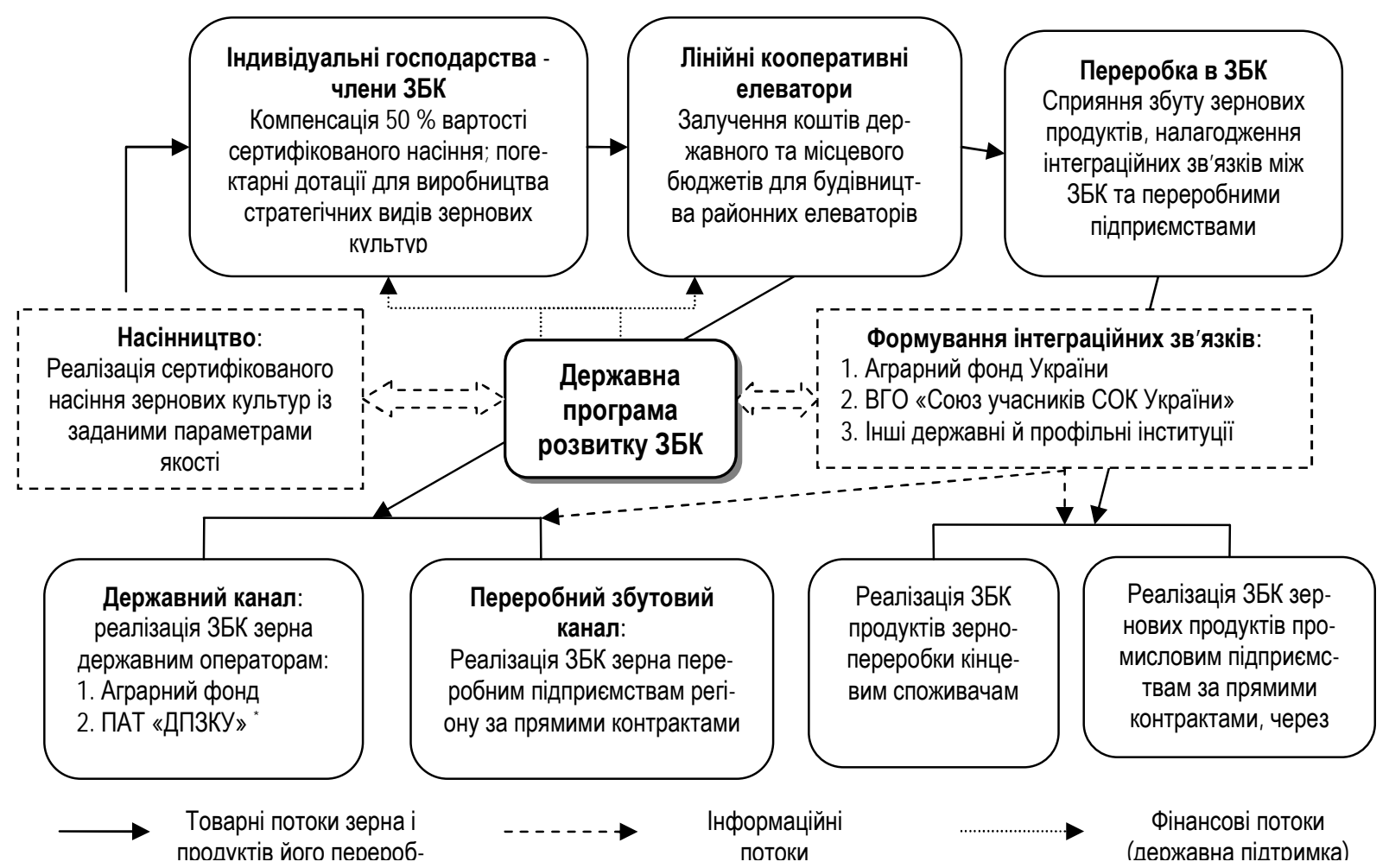

*ПАТ «ДПЗКУ» - ПАТ «Державна продовольчо-зернова корпорація України».

Рис. 2. Головні напрями і форми взаємодії держави й суб'єктів ринку в ході реалізації Державної програми розвитку ЗБК *

*авторська розробка

Для активізації інтеграційних механізмів держава застосовує селективні регуляторні заходи (див. рис. 2). Головними 3 них є компенсація $50 \%$ вартості сертифікованого насіння вітчизняного виробництва, погектарні дотації для виробництва зернових культур із заданими параметрами якості для індивідуальних господарств - членів ЗБК, залучення бюджетних коштів для будівництва лінійних кооперативних елеваторів, часткові державні закупівлі зерна у ЗБК, залучення до процесу формування інтеграційних зв'язків інформаційних і організаційних ресурсів Аграрного фонду, інших державних і профільних інституцій.
Практичне впровадження Державної цільової програми підтримки розвитку зернових багатофункціональних кооперативів передбачено в три етапи, кожний 3 яких охоплює два роки (таблиця 2). На першому початковому етапі шляхом реалізації комплексу селективних регуляторних заходів держави відбувається формування регіональних ЗБК, будівництво кооперативних елеваторів за рахунок власних i залучених коштів, у т.ч. бюджетних, формування системи інтеграційних зв'язків новостворених кооперативів із іншими суб' єктами ринкової системи.

Таблиця 2

Мета, завдання й етапи Державної цільової програми розвитку зернових багатофункціональних кооперативів в Україні *

\begin{tabular}{|c|c|}
\hline $\begin{array}{c}\text { Складові } \\
\text { елементи }\end{array}$ & 3мicm \\
\hline Головна мета & $\begin{array}{l}\text { Зменшення витрат індивідуальних господарств у процесі виробництва та реалізації зерна } \\
\text { й продуктів його переробки, а також задоволення внутрішнього попиту на стратегічні } \\
\text { види зернових культур, зокрема, продовольчої пшениці } 2 \text { класу, пшениці твердих сортів, } \\
\text { жита, зернобобових культур }\end{array}$ \\
\hline Завдання & $\begin{array}{l}\text { 1. Державна підтримка розвитку регіональних ЗБК, члени яких виробляють, зберігають, } \\
\text { частково переробляють стратегічні види зернових культур } \\
\text { 2. Узгодження внутрішнього попиту й пропозиції стратегічних видів зерна } \\
\text { 3. Реалізація інноваційного потенціалу відтворювального розвитку індивідуального сек- } \\
\text { тору зернового ринку } \\
\text { 4. Впровадження ефективних форм взаємодії ЗБК з іншими учасниками процесу відтво- } \\
\text { рення на засадах узгодження їх економічних інтересів }\end{array}$ \\
\hline
\end{tabular}


Продовження табл.2

\begin{tabular}{|c|c|}
\hline Завдання & $\begin{array}{l}\text { 5. Формування економічних передумов для стійкого розвитку мережі регіональних ЗБК } \\
\text { після закінчення терміну реалізації програми }\end{array}$ \\
\hline $\begin{array}{l}\text { I eman (1-2 piк) } \\
\text { Початковий: } \\
\text { формування інте- } \\
\text { граційних зв'язків }\end{array}$ & $\begin{array}{l}\text { Селективні регуляторні заходи держави: } \\
\text { 1. Компенсація } 50 \text { \% вартості сертифікованого насіння зернових культур, виробленого } \\
\text { українськими насіннєвими господарствами, для членів ЗБК. } \\
\text { 2. Погектарні дотації для виробництва стратегічних зернових культур із заданими пара- } \\
\text { метрами якості для індивідуальних господарств - членів ЗБК. } \\
\text { 3. Залучення бюджетних коштів для будівництва кооперативних елеваторів } \\
\text { 4. Інформаційне забезпечення процесу формування інтеграційних зв’язків державними } \\
\text { інституціями (Аграрний фонд, регіональні Департаменти агропромислового розвитку, } \\
\text { Департамент науково-освітнього забезпечення та розвитку підприємництва на селі Мініс- } \\
\text { терства аграрної політики та продовольства України та інші) }\end{array}$ \\
\hline $\begin{array}{l}\text { II етап (3-4 рік) } \\
\text { Стабілізація: } \\
\text { посилення існую- } \\
\text { чих зв'язків, пря- } \\
\text { мі контракти ЗБК } \\
\text { з переробними } \\
\text { підприємствами }\end{array}$ & $\begin{array}{l}\text { Селективні регуляторні заходи держави: } \\
\text { 1. Компенсація } 50 \text { \% вартості сертифікованого насіння зернових культур, виробленого } \\
\text { українськими насіннєвими господарствами, для членів ЗБК. } \\
\text { 2. Залучення бюджетних коштів для будівництва кооперативних елеваторів } \\
\text { 3. Інформаційне забезпечення процесу формування інтеграційних зв’язків державними і } \\
\text { профільними інституціями (зокрема, ВГО «Союз учасників СОК України», іншими } \\
\text { об’єднаннями агровиробників), їх скоординована співпраця }\end{array}$ \\
\hline $\begin{array}{l}\text { III етап (5-6 piк) } \\
\text { Розвиток: } \\
\text { Створення мно- } \\
\text { жини стійких } \\
\text { зв'язків, освоєння } \\
\text { нових ринків збу- } \\
\text { ту }\end{array}$ & $\begin{array}{l}\text { Селективні регуляторні заходи держави: } \\
\text { 1. Сприяння реалізації продукції ЗБК через Аграрну біржу } \\
\text { Діяльність профільних інституиій: } \\
\text { Створення профільної інституції зернового напряму (наприклад, Союз зернових обслуго- } \\
\text { вуючих кооперативів України), яка буде виконувати функції інформаційного забезпечен- } \\
\text { ня та координації зв’язків ЗБК з переробними підприємствами та іншими суб'єктами ри- } \\
\text { нку }\end{array}$ \\
\hline $\begin{array}{l}\text { Очікувані } \\
\text { ефекти }\end{array}$ & $\begin{array}{l}\text { 1. Забезпечення доступу індивідуальних господарств, зокрема господарств населення, як } \\
\text { членів ЗБК до державної підтримки та ринкової інфраструктури } \\
\text { 2. Зниження витрат, підвищення ефективності господарювання суб’єктів індивідуального } \\
\text { сектору зернового ринку } \\
\text { 3. Диверсифікація каналів реалізації зернових культур } \\
\text { 4. Впровадження та розвиток ефективних форм взаємодій ЗБК з іншими суб'єктами рин- } \\
\text { ку, державними й профільними інституціями } \\
\text { 5.Узгодження внутрішнього попиту й пропозиції стратегічних видів зерна } \\
\text { 6. Позитивні структурні зміни у зерновиробництві, формування якісної сировинної бази } \\
\text { для розвитку експорту вітчизняних зернових продуктів, зокрема борошна. }\end{array}$ \\
\hline
\end{tabular}

*авторська розробка

На першому етапі важливим завданням держави $є$ виконання усіх зобов'язань у частині повноти й своєчасності виплат компенсацій і погектарних дотацій для індивідуальних господарств - членів ЗБК, а також гарантований збут їх продукції. При цьому головним збутовим каналом може бути державний, водночас на наступних етапах Програми у міру збільшення кількості зв'язків і взаємодій ЗБК зростатиме роль переробного каналу реалізації їх продукції за прямими контрактами із регіональними переробними підприємствами (див. рис. 2). Необхідною умовою отримання погектарної дотації є використання зерновиробниками - членами ЗБК - сертифікованого насіння вітчизняного виробництва та реалізація культур за державним або переробним збутовим каналом (однак не посередницьким «іншим» каналом). Розмір погектарної дотації залежатиме від обсягів посівних площ стратегічних видів культур. Так, у країнах $\mathrm{C}_{\text {в- }}$ росоюзу додаткові виплати для твердої пшениці, що вирощується в традиційних зонах, складає 344,5 євро/га, однак у випадку перевищення гаранто- ваних площ посівів розмір таких виплат пропорційно зменшується [4].

Слід відзначити, що термін дії погектарних дотацій складає два роки. Очікується, що в умовах стабільного внутрішнього попиту та налагодження зв'язків ЗБК з переробними підприємствами виробництво стратегічних видів зернових культур буде зростати без заходів державної підтримки. Водночас 3 метою реалізації інноваційного потенціалу зернового ринку на другому етапі Програми запропоновано залишити для членів ЗБК компенсацію $50 \%$ вартості сертифікованого насіння зернових культур, а також передбачити механізми залучення бюджетних коштів для будівництва лінійних кооперативних елеваторів (див. табл. 2).

Загалом у міру розвитку та формування багаторівневої системи інтеграційних зв'язків між ЗБК та іншими учасниками ринкового процесу відтворення ступінь державної підтримки й кількість селективних регуляторних заходів зменшується від чотирьох на першому етапі до одного на третьому етапі. При цьо- 
му передбачено зростання ролі профільних інституцій в інформаційному забезпеченні, а також створення профільної організації виключного зернового спрямування (наприклад, Союз зернових обслуговуючих кооперативів України), яка буде виконувати функції інформаційного забезпечення та координації зв'язків ЗБК з переробними підприємствами та іншими суб'єктами ринку, співпрацювати 3 державними інституціями.

Третій етап Програми зорієнтований на подальший розвиток ефективних форм взаємодій ЗБК з суб'єктами ринку та державою, які були виявлені за результатами моніторингу впливу заходів державної підтримки на зміну показників розвитку зернової кооперації в Україні. На цьому етапі подальша диверсифікація збутових каналів може здійснюватися за рахунок біржового напрямку (див. табл. 2). Тому заходами стимулювання реалізації продукції кооперативу через Аграрну біржу можуть стати акредитація ЗБК за спрощеною схемою та надання канікул зі сплати біржового збору на період до 12 міс., що дозволить кооперативам одержати стабільний канал реалізації товарів за ринковими цінами та зарекомендувати себе на біржі як надійного постачальника продукції високої якості [5, с. 36].

Головними очікуваними ефектами від впровадження Програми, що пропонується, є підвищення ефективності індивідуальних господарств - членів ЗБК, забезпечення їх доступу до державної підтримки та засобів ринкової інфраструктури, диверсифікація збутових каналів, узгодження внутрішнього попиту й пропозиції стратегічних видів зернових культур (див. табл. 2). Слід відзначити, що можливі позитивні зміни у видовій структурі зерновиробництва, насичення внутрішнього ринку якісним зерном із заданими параметрами якості поступово сформує сировинну базу для розвитку експортного напрямку в діяльності зернопереробних підприємств, зокрема, борошномельних. Відтак, реалізація Програми є першим кроком на шляху подолання існуючих проблем зовнішньоекономічної інтеграції вітчизняного ринку борошномельно-круп’яної продукції до глобального ринку.

Висновки та перспективи подальших досліджень. У ході дослідження встановлено, що причинами інституційної неспроможності програмних документів у сфері аграрної, у т.ч. зернової кооперації, $\epsilon$ недостатній рівень їх ресурсного, організаційного й контролюючого забезпечення. Практика свідчить про слабкий вплив формальних інститутів на реалізацію потенціалу кооперації індивідуального сектору зернового ринку України, що актуалізує завдання онов- лення методологічних підходів до формування програмних документів.

Інтеграційний підхід, що покладений в основу розробки Програми розвитку ЗБК в Україні, фокусує увагу на становленні й розвитку ефективних форм взаємодій між кооперативами, державними й профільними інституціями, іншими суб'єктами ринку зерна й продуктів його переробки на засадах узгодження їх економічних інтересів для досягнення цільового орієнтиру. Держава за допомогою селективних регуляторних заходів керує процесами формування та перерозподілу товарних потоків у багаторівневій ринковій системі, створюючи стимули для об'єднання індивідуальних господарств у ЗБК та розвитку інтеграційних зв'язків із переробними підприємствами. По суті держава ініціюе створення $i$ підтримку цільового ланиююга доданої вартості, здатного об'єднати певних учасників виробничо-збутового процесу.

Головними селективними заходами держави $\epsilon$ компенсація 50 \% вартості сертифікованого насіння вітчизняного виробництва, погектарні дотації для виробництва стратегічних зернових культур для індивідуальних господарств - членів ЗБК, залучення бюджетних коштів для будівництва кооперативних елеваторів, розвиток державного, переробного та біржового каналів збуту зерна. Практичне впровадження Програми передбачено в три дворічні етапи, при цьому у міру розвитку та ускладнення системи інтеграційних зв'язків між ЗБК та іншими учасниками процесу відтворення кількість селективних регуляторних заходів зменшується від чотирьох на першому етапі до одного на третьому етапі. Одним із очікуваних ефектів впровадження Програми є формування ефективних форм взаємодії ЗБК з іншими суб'єктами ринку, яке створить передумови для відтворювального розвитку кооперативів без підтримки держави.

Наукова новизна проведеного дослідження полягає в обгрунтуванні сутності інтеграційного підходу до формування Програми розвитку зернових багатофункціональних кооперативів в українських реаліях. Теоретичне значення результатів дослідження полягає в розвитку концептуальних положень ринкової інтеграції в інституційному вимірі, практичне значення визначається можливістю використання авторських розробок державними інституціями в ході розробки програмних документів у сфері зернової кооперації. Перспективи подальших досліджень полягають у використанні інтеграційного підходу, природу якого розкрито у даній статті, для обгрунтування компонентів формальних інститутів кооперації на стратегічних агропродовольчих ринках України для їх ефективного функціонування.

\section{Література}

1. Стратегія розвитку аграрного сектору економіки на період до 2020 р.: затверджена розпорядженням Кабінету Міністрів України № 806-р від 17.11.2013 p. URL: http://zakon5.rada.gov.ua/laws/show/806-2013$\% \mathrm{D} 1 \% 80$ (дата звернення 29.05.2018).

2. Корінець Р. Я., Малік М.Й. Інформаційне забезпечення сільськогосподарської обслуговуючої кооперації в Україні // Економіка АПК. 2016. № 8. С. 61-70. 
3. Манжура О.В. Інтеграційні процеси у сільськогосподарській кооперації України // Менеджер ДонДУУ. 2014. №1(67). С. 21-24.

4. Молдаван Л. В., Шубравська О.В. Інвестиційні пріоритети у сфері розвитку агропромислового виробництва України та механізми їх реалізації // Економіка України. 2015. № 4 (641). С. 78-87.

5. Паска І.М. Ефективність моделей кооперації сільськогосподарських підприємств // Економіка та держава. 2015. №9. C. 33-36.

6. North D. Institutions, Institutional Change and Economic Performance. Cambridge: Cambridge University Press, 1990. 620p.

7. Furubotn E. G., Richter R. Institutions and Economic Theory: The Contribution of the New Institutional Economics. URL: https://www.press.umich.edu/6715/institutions and economic theory (application date May 29, 2018).

8. Офіційний сайт Міністерства аграрної політики та продовольства: Інформаційно-аналітичні матеріали. URL: http://minagro.gov.ua/ministry?nid=15750 (дата звернення 29.05.2018).

9. Офіційний сайт Державної служби статистики України. URL: //http://www.ukrstat.gov.ua (дата звернення 29.05.2018).

10.Про кооперацію: Закон України № 1087-IУ від 10 липня 2003 р. за станом на 06.11.2014 p. URL: http://zakon3.rada.gov.ua/laws/show/1087-15 (дата звернення 29.05.2018).

11. Про сільськогосподарську кооперацію: Закон України № 469/97-ВР від 17 липня 1997 р. за станом на 19.01.2013 p. URL: http://zakon3.rada.gov.ua/laws/show/469/97 (дата звернення 29.05.2018).

12. Програма становлення і розвитку сільськогосподарських обслуговуючих кооперативів як неприбуткових організацій: затверджена Наказом Міністерства аграрної політики України № 168 від 31.08 .2000 р. Втрата чинності на підставі Наказу № 304 від 19.06.2017 p. URL: http://consultant.parus.ua/?doc=00LDM12680 (дата звернення 29.05.2018).

13. Державна цільова економічна програма підтримки розвитку сільськогосподарських обслуговуючих кооперативів на період до 2015 року: затверджена Постановою Кабінету Міністрів України №557 від 03.06.2009 p. Втрата чинності на підставі Постанови КM № 704 від 07.07.2011 p. URL: http://zakon0.rada.gov.ua/laws/show/557-2009-\%D0\%BF (дата звернення 29.05.2018).

14. Нікішина О.В. Трансформаційний вплив інтеграційних процесів на відтворювальний розвиток зернового ринку України // Економічні інновації. 2016. Вип. 62. С. 232-241.

15. Nikishina O. V. Regulatory Elasticity the Integrated Flour Market in Ukraine. Stredoevropsky vestnik pro vedu a vyzkum. 2014. №2 (4). P. 53-59.

Стаття надійшла 02.06.2018 Стаття прийнята до друку 16.07.2018 Доступно в мережі Internet 17.10.2018

\author{
Никишина О.В. \\ доктор экономических наук, старший научный сотрудник \\ отдел рыночных механизмов и структур \\ Институт проблем рынка и экономико-экологических исследований НАН Украины \\ Французский бульвар, 29, г.Одесса, Украина, 65044 \\ E-mail: ksenkych@gmail.com
}

\title{
ИНТЕГРАЦИОННЫЙ ПОДХОД К ФОРМИРОВАНИЮ ПРОГРАММЫ РАЗВИТИЯ ЗЕРНОВЫХ МНОГОФУНКЦИОНАЛЬНЫХ КООПЕРАТИВОВ В УКРАИНЕ
}

Одной из институциональных проблем развития зерновой кооперации в Украине является преимущественная ориентация программных документов на развитие одного локального сектора рынка. В условиях ограниченности бюджетных ресурсов актуализируется задача их использования для системного решения проблем развития нескольких секторов товарного рынка по этапам воспроизводственной цепи. Следовательно, возникает необходимость в изменении научного и методического подходов к разработке формальных институтов.

Целью статьи является разработка на основе интеграционного подхода Государственной целевой программы развития зерновых многофункциональных кооперативов в Украине. Для достижения цели в статье решены следующие задачи: (1) анализ проблем фрункционирования фрормальных институтов в сфрере аграрной кооперации; (2) определение сущности интеграционного подхода; 
(3) обоснование мероприятий селективного воздействия государства на формирование интеграционных связей между участниками целевого процесса воспроизводства в разрезе этапов Программы.

Сущность интеграционного подхода заключается в целевом формировании, сочетании и использовании товарных и организационных ресурсов субъектов рынка и других участников процесса воспроизводства, которое осуществляет государство на основе согласования их экономических интересов. Целью Программы является уменьшение расходов индивидуальных хозяйств в процессе производства и реализации зерна и продуктов его переработки, а также удовлетворение внутреннего спроса на стратегические виды зерновых культур. Главная идея, заложенная в основу Программы, заключается в предоставлении государством селективной поддержки многофункциональным кооперативам, члены которых производят, хранят и перерабатывают стратегические виды зерна. Практическое внедрение Программы предусмотрено в течение трех двухлетних этапов, при этом количество селективных мер уменьшается от четырех на первом этапе до одного на третьем этапе.

Главным ожидаемым эффектом от внедрения Программы является формирование эффективных фрорм взаимодействия кооперативов с другими субъектами рынка, различными институтами путем их объединения в целевую цепочку воспроизводства стратегических видов зерна. Практическое достижение данного эфффекта создаст предпосылки для развития многофункциональных кооперативов без поддержки государства. Теоретическое значение исследования заключается в развитии концептуальных положений рыночной интеграции в институциональном измерении, практическое - в использовании авторских разработок государственными институциями в ходе обоснования программных документов.

Ключевые слова: зерновая кооперация, индивидуальные хозяйства, многофункциональные кооперативы, интеграционные взаимодействия, селективные меры.

\author{
Nikishina 0. \\ Doctor of Economics, Senior Researcher \\ Department of Market Mechanisms and Structures \\ Institute of Market Problems and Economic \& Ecological Research \\ of National Academy of Sciences of Ukraine \\ Frantsuzskiy boulevard, 29, Odesa, Ukraine, 65044 \\ E-mail: ksenkych@gmail.com
}

\title{
INTEGRATION APPROACH TO FORMATION OF THE PROGRAMME OF THE DEVELOPMENT OF GRAIN MULTIFUNCTIONAL COOPERATIVES IN UKRAINE
}

One of the institutional problems of development of grain cooperation in Ukraine is the predominant orientation of program documents for the development of a single local market sector. In the conditions of the limited budget resources the task of their use is actualized for a systemic solution of the problems of development of several sectors of the commodity market in stages of the reproduction chain. Thus, there is a need in the change of scientific and methodical approaches to the development of formal institutions.

The aim of the article is to develop the State Target Development Program of grain multifunctional cooperatives in Ukraine on the basis of the integration approach. To achieve the aim the following tasks have been solved in the article: (1) the analysis of the problems of functioning of formal institutes in field of agrarian cooperation; (2) definition of the essence of the integration approach; (3) justification of the measures of selective influence of the state on the formation of integration ties between the participants in target reproduction process in the context of the Program stages.

The essence of the integration approach is in target formation, combination and use of commodity and organizational resources of market subjects and other participants in the process of reproduction, which the state carries out on the basis of coordination of their economic interests. The purpose of the Program is to reduce the costs of individual farms in the process of production and sale of grain and products of its processing, as well as satisfaction of domestic demand for strategic types of grain crops. The main idea that laid the Program basis is to provide the state selective support for multifunctional cooperatives, whose members produce, store and process strategic types of grain. The practical implementation of the Program is foreseen in three biennial stages, the number of selective measures decreases from four at the first stage to one at the third stage.

The main expected effect of the implementation of the Program is the formation of effective forms of cooperatives interaction with other market units, different institutions by combining them into the target chain of reproduction of strategic types of grain. Practical achievement of this effect will create preconditions for 
the development of multifunctional cooperatives without the support of the state. The theoretical significance of the research is in development of conceptual provisions of market integration in the institutional dimension, the practical one - in the use of author's works by the state institutions during the substantiation of the program documents.

Keywords: grain cooperatives, individual farms, multifunctional cooperatives, integration interactions, selective measures.

\section{References}

1. Stratehiia rozvytku ahrarnoho sektoru ekonomiky na period do 2020 r.: Zatverdzhena rozporiadzhenniam Kabinetu Ministriv Ukrainy № 806-r vid 17.11.2013 r. (2013). Retrieved May 29, 2018, from http://zakon5.rada.gov.ua/laws/show/806-2013-p

2. Korinets, R. Ya., \& Malik, M. Y. (2016). Informatsiine zabezpechennia silskohospodarskoi obsluhovuiuchoi kooperatsii v Ukraini. Ekonomika APK, (8), 61-70.

3. Manzhura, O. V. (2014). Intehratsiini protsesy u silskohospodarskii kooperatsii Ukrainy. Menedzher DonDUU, (1 (67)), 21-24.

4. Moldavan, L. V., \& Shubravska, O. V. (2015). Investytsiini priorytety u sferi rozvytku ahropromyslovoho vyrobnytstva Ukrainy ta mekhanizmy yikh realizatsii. Ekonomika Ukrainy, (4 (641)), 78-87.

5. Paska, I. M. (2015). Efektyvnist modelei kooperatsii silskohospodarskykh pidpryiemstv. Ekonomika Ta Derzhava, (9), 33-36.

6. North, D. (1990). Institutions, Institutional Change and Economic Performance. Cambridge: Cambridge University Press.

7. Furubotn, E. G., \& Richter, R. (2005). Institutions and Economic Theory: The Contribution of the New Institutional Economics. $\quad$ Retrieved May 29, 2018, $\quad$ from https://www.press.umich.edu/6715/institutions and economic theory

8. Ofitsiinyi sait Ministerstva ahrarnoi polityky ta prodovolstva: Informatsiino-analitychni materialy. (2018). Retrieved May 29, 2018, from http://minagro.gov.ua/ministry?nid=15750

9. Ofitsiinyi sait Derzhavnoi sluzhby statystyky Ukrainy. (2018). Retrieved May 29, 2018, from http://ukrstat.gov.ua/

10. Pro kooperatsiiu: Zakon Ukrainy № 1087-IU vid 10 lypnia 2003 r. za stanom na 06.11.2014 r. (2014). Retrieved May 29, 2018, from http://zakon3.rada.gov.ua/laws/show/1087-15

11. Pro silskohospodarsku kooperatsiiu: Zakon Ukrainy № 469/97-VR vid 17 lypnia 1997 r. za stanom na 19.01.2013 r. (2013). Retrieved May 29, 2018, from http://zakon3.rada.gov.ua/laws/show/469/97

12. Prohrama stanovlennia i rozvytku silskohospodarskykh obsluhovuiuchykh kooperatyviv yak neprybutkovykh orhanizatsii: Zatverdzhena Nakazom Ministerstva ahrarnoi polityky Ukrainy № 168 vid 31.08.2000 r. Vtrata chynnosti na pidstavi Nakazu № 304 vid 19.06.2017 r. (2017). Retrieved May 29, 2018, from http://consultant.parus.ua/?doc=00LDM12680

13. Derzhavna tsilova ekonomichna prohrama pidtrymky rozvytku silskohospodarskykh obsluhovuiuchykh kooperatyviv na period do 2015 roku: Zatverdzhena Postanovoiu Kabinetu Ministriv Ukrainy №557 vid 03.06.2009 r. Vtrata chynnosti na pidstavi Postanovy KM № 704 vid 07.07.2011 r. (2011). Retrieved May 29, 2018, from http://zakon0.rada.gov.ua/laws/show/557-2009-п

14. Nikishyna, O. V. (2016). Transformatsiinyi vplyv intehratsiinykh protsesiv na vidtvoriuvalnyi rozvytok zernovoho rynku Ukrainy. Ekonomichni Innovatsii, (62), 232-241.

15. Nikishina, O. V. (2014). Regulatory Elasticity the Integrated Flour Market in Ukraine. Stredoevropsky Vestnik Pro Vedu a Vyzkum, (2 (4)), 53-59.

Received 2 June 2018

Approved 16 July 2018

Available in Internet 17.10.2018

Цитування згідно ДСТУ 8302:2015

Нікішина О. В. Інтеграційний підхід до формування програми розвитку зернових багатофункціональних кооперативів в Україні // Економіка харчової промисловості. 2018. Т. 10, Вип. 3. С. 3-12; doi: 10.15673/fie.v10i3.1067

Cite as APA style citation

Nikishyna, O. (2018). Integration approach to formation of the programme of the development of grain multifunctional cooperatives in Ukraine. Food Industry Economics, 10(3), 3-12; doi: 10.15673/fie.v10i3.1067 